\title{
The Elusive Search for Nora Luca: Tony Gatlif's Adventures in Gypsy Land.
}

\author{
Sylvie Blum-Reid, University of Florida
}

\author{
Foreigner: \\ Who does not know, \\ Who is from another nation, \\ Who does not belong to a family, \\ Who does not belong to the matter under discussion, \\ That is found against nature in man's body \\ (Larousse dictionary) $)^{1}$
}

French cinema and criticism have slowly addressed immigrant and marginalized cultures and Gypsy filmmaking ${ }^{2}$. Gypsy studies remain in a splendid isolation as can attest a recent socio-historical approach to European Gypsies (Lucassen, Willens \& Cottaar, 1998). This essay proposes to broaden the approach to contemporary Gypsy culture, and more specifically looks at a Gypsy film, focusing on the plight of (Romanian) Gypsy communities in French cinema. This minority is absent from any discourse or studies on contemporary French culture and identity and will be explored through the lens of

\footnotetext{
${ }^{1}$ Definition encountered in Clément Lépidis, L’Arménien (Paris: Seuil, 1973). A novel on Armenians in France: Etranger:

Qui ne connaît pas

Qui est d'une autre nation

Qui ne fait pas partie d'une famille

Qui n'appartient pas à la chose dont on parle

Qui se trouve contre nature dans le corps de l'homme

${ }^{2}$ I use the term 'Gypsy' here, although the terms used in France fluctuate between 'gitan', 'tzigane',

'Romanichel', 'manouche' and 'Bohémien'. Gypsies discard the 'Gypsy' term and call themselves 'roma' or 'manouche' according to Gatlif.

Portal Journal of Multidisciplinary International Studies Vol. 2, No. 2 July 2005

ISSN: $1449-2490$

http://epress.lib.uts.edu.au/journals/portal/splash/
} 
filmmaker Tony Gatlif, writer and director of the 1997 film Gadjo Dilo (The Crazy Foreigner). ${ }^{3}$

Multiple readings of Gadjo Dilo can be made. I will point to several approaches, which are unavoidable considering the richness of the film and its scope. I discuss the place of Gatlif's film amidst French cinema, and its reception. I investigate the genre of the film, which may fit into the road movie category as the film engages in travels. A postcolonial reading underlines the analysis of the film and the use of the term 'Other' fits the representation of the main protagonist of Gadjo Dilo. The project is informed by interesting recent studies of Gypsy laws. I otherwise situate this essay in what is best characterized as a 'cultural studies' approach — an approach to a culture, some of its products, and the vision of a filmmaker who is a cultural other. Last, I suggest that a psychological analysis is necessary especially when one considers all the items listed above, and particularly the fact that the narrative follows a young male character searching for his father and in love with a voice.

Gadjo Dilo proposes a vista into the world of Romanian Gypsy life from the perspective of a young white French male traveler. The young man walks the icy and deserted roads of Romania and confesses that 'he hates to walk' as the film credits begin to roll. Unfortunately, there will be a lot of walking in the film. The young man, Stéphane, (played by one of France's leading French young actors, Romain Duris, who is a recurring figure in Gatlif's films) is retracing his father's footsteps into the eastern European country of Romania where the latter would come and collect audio samples for his ethnographic research. Equipped with a high tech cassette player and tapes, Stéphane searches for Nora Luca, a female singer whose voice recorded by his father shapes the film and gives it breath and pretext. More or less adopted by a group of Gypsies and their patriarch, Izidor, the young traveler is introduced to the pain, grief and racism endured by Romanian Gypsies, or Roma people, over centuries. Tony Gatlif, a Gypsy filmmaker of

\footnotetext{
${ }^{3}$ Gadjo Dilo, ( The Crazy Stranger) [motion picture] written and directed by Tony Gatlif, produced by Doru Mitran, Original Score Tony Gatlif, Starring Romain Duris, Rona Hartner and Isidor Serban. New Yorker Video, 1999
} 
Berber and Andalusian descent and a musician who has been living in Spain and France, and has sometimes been mistaken for a Romanian Gypsy, produces an interesting reversal, as the young French man becomes the 'Other', the foreigner, the gadje, only to be rescued by two prominent community figures: the old man Izidor, leader of the Gypsy village, and the young Gypsy woman, Sabina. The woman acts as the reluctant translator and interpreter between Stéphane and the Gypsy community because she had previously traveled and lived in Belgium and 'speaks Belgian'. As Ien Ang has noted, Gypsies are 'one of the oldest cultural “Others” within Europe’s borders, a group of people whose inferior status has not changed for centuries ... because they do not form or belong to a "nation”' (Ang 1992, 29). In the nineteenth century, Gypsies were also viewed as 'Europe's Negroes' (The Economist, 11 September 1999) or also a splinter group from the Jews (Lucassen, Willems \& Cottaar 1998, 23 and note 2).

The passionate search for the elusive Nora Luca, or the search for a voice, remains inconclusive, as the spectator (and Stéphane) never knows if the woman/Sabina is the authentic Nora Luca. Yet, the search for Nora Luca drives the narrative and transports the spectator into the Romanian countryside. The search may simply evidence a reflexive search - that of the traveler inside his own self, mediated by the discovery and closeness to the 'Other' culture. In the meantime, and thanks to the woman's assistance, Stéphane is able to sample sounds and music of a disappearing culture in order to preserve it, as his ethnographer/musicologist-father did before him. This trilingual road movie (that speaks a mix of French and also Romanian and Rom, the language of Roma people) addresses the Western urge to preserve Gypsy memory and the quest for ethnographic collectibles and memorabilia. In what classifies as a road movie, a genre that Tony Gatlif recognizes as his preferred mode- 'je fais des films sur la 'route' parce que la route est un pays pour moi' ('I make films about the road for the road is my country'), (Gatlif 2004) yet is a reworking of the genre, the boundaries - which are usually applied to the vast American landscapes and roadways - are stretched. Technically speaking, the film is a semi-road movie as it does not rely primarily on the use of the cars that dominate American narratives. It fits more into the European road movie category discussed by David Laderman (Laderman 2002, 265). Road movies are atypical in French cinema. Few films 
have explored the Eastern European landscape. Gadjo Dilo in a travel narrative where the main protagonist is hitchhiking in the first part, then acquires a car that constantly breaks down in the second part. My analysis of the film is informed by postcolonial theory about the 'Other' with the inclusion of the Gypsy as Europe’s others, the place of Gypsies in France relegated to the margins. It is an extremely postmodern film in its representation of gender and space. The countryside scanned by the lens is bare and frozen, paved by mileposts, yet Gypsy women enter that space and inhabit it fully, despite their inferior status. By inferior, I merely point to their separate space and function in the movie, as caregivers and cooks, since as we will see later, Gypsy culture gives women a high status. They have become the repository of collective memory and audio soundtracks and the objects of an endless search.

The film (produced by a French production house, and filmed on location) could have stayed in France, yet it opted for a journey eastward, into Eastern Europe, where once observed from that location, concepts of borders, gender and exoticism are interestingly displaced and have shifted. For a French moviegoer, Romania evokes an exotic, oriental space, never quite traveled. It arouses a feeling, briefly described by Roland Barthes who romanticized the dirt roads of Romania seen in a 1921 Kertesz photograph, a photograph that transcends itself. The photograph shows a blind Gypsy violinist being led by a boy, 'its texture gives me the certainty of being in Central Europe...I recognize, with my whole body, the straggling villages I passed through on my long ago travels in Hungary and Rumania' (Barthes 1981, 45).

Exilic and diasporic filmmakers who relocate in the West, like Tony Gatlif, turn to their 'indigenous local culture' or back to an individual experience shaped by exile to 'create a third space of alterity, creativity and insights,' at least if one observes Hamid Naficy's reading of diasporic filmmakers (Naficy 2001, 82). However the case of Tony Gatlif might be more complex when it comes to identifying the 'local' part of his culture since he is not originally from Eastern Europe, but rather Algeria, and considers himself a 'Mediterranean' and is comfortable living in Spain and France. While Gatlif deploys every possible strategy to target and speak for the Gypsy communities, the film reflects 
on such a community's absence of borders and the impossibility of mapping its territory. It goes beyond familiar borders and responds to the call of the road, a familiar script in many of Gatlif's films and especially his latest one, Exils (Gatlif 2004).

Gatlif's attempts to merge with the French film world were not successful until he assumed his identity as a Gypsy (Naficy 2001, 99). He indeed might be the first Gypsy filmmaker in the history of French cinema. Needless to say, the reception of Gatlif's film was and still is highly controversial; the film was not well received by Roma communities in the United States and in Romania, whereas its critical acclaim was strongest among non-Gypsy Western communities in France, Germany and the United States, receiving a ten-minute standing ovation at the Locarno film festival premiere. Most critics 'noted its emotional effect on Western audiences and ... loaded their reviews with adjectives such as "authentic", "passionate", "visceral”, "pulsating”, and "fullblooded"' (Thompson 2000).

At first glance an interesting shift occurs in Gadjo Dilo as it includes the Gypsies' perspective on a gadje, a foreigner, yet the point of view of Stéphane, that of the camera or that of Tony Gatlif takes over, bounces back and is also cast on 'them,' Romanian Gypsies, practicing a doubly-exoticizing gaze-by positing the Gypsies as exotic, but also Stéphane, the French man with 'pink skin', as an exotic creature for them.

A recent domain of investigation in Gypsy studies (Weyrauch \& Bell 2001) has been Gypsy law, which remains extremely strong considering their long history and diasporic movements. According to Gypsy law a foreigner is an impure body that is polluted. The Rom criteria for judging their own people are extremely strict, delimiting clear boundaries between 'pure' and 'impure’.

Furthermore, not only do the Gypsies consider non-Gypsies polluted, they also believe that Gypsy names and rituals lose magical effectiveness if uttered to gaje. Consequently, the Gypsies believe they should approach and respond to the gaje with caution, especially 
if the gaje profess good intentions, and claim to serve the best interest of the Gypsies. (Weyrauch \& Bell 2001, 25).

Therefore, according to the Gypsy, the foreigner is 'uncivilized.' This view reverses the common representation of Gypsies by non-Gypsy cultures that perceives the Gypsy mode of life as primitive, exotic and dangerous. When Stéphane enters the village, he brings in his uncivilized and 'bum-like’ manners, provoking laughter, sarcasm and disbelief among the villagers who are afraid and wary of him, as a potential chicken thief and rapist. Interestingly, Stéphane appears as an effeminate character in several instances in the movie, casting a doubt on the masculinity of the French male traveler. This trait provides an element of comic relief to the narrative that in itself operates on both tragic and comic levels. This position places Stéphane in closer contact with the women in the community. An example of this proximity takes place when Stéphane disrupts the cultural codes and cleans up Izidor's house, a task traditionally assigned to women. His search for Nora Luca is therefore helped by his closeness to women and his arrival into their space. ${ }^{4}$

Gypsy women have the leading roles not only in the film but also in Rom cultures. In Gadjo Dilo, they are the sometimes-hesitant transmitters of Gypsy culture as well as gobetweens and translators. Sabina acts as Stéphane’s translator and spokesperson for the villagers. She is also a dancer and singer, whose dance movements usher a certain orientalizing function in the movie. Granted, Romania is part of the Orient for a Western French critic and audience.

At the close of the film, Stéphane performs a ritualistic shamanic burial of the tapes next to a milepost, in a dance witnessed by Sabina, who has awoken from her sleep in his car. He actually appropriates a ritual he has seen performed by Izidor by a grave at a funeral. One does not know if Sabina and Stéphane are going any place, away from the village, or if they are just traveling to the city. How are we to interpret the last sequence? Should one read that the past is buried with the recordings of disappearing tunes therefore

\footnotetext{
${ }^{4}$ Interestingly, Romain Duris, the actor, is often in the position of proximity to women in the role of 'friend' in films such as in Cédric Klapisch's L'Auberge espagnole (2002) and more recently Les Poupées russes (2005).
} 
privileging the persistence of oral history over technological progress and museum culture? If one senses the utter urgency of the gesture, then how can one explain that Stéphane does not destroy the expensive tape recorder?

If gender remains an important factor, male bonding is a key element in the narrative, with the friendship between Izidor and Stéphane conducive to his quasi- adoption as a son by Izidor prior to the loss of Izidor's 'real' son, Adriani, a victim of the villagers' pogrom at the end of the film.

The question remains regarding the intentions of the filmmaker as to which society he is actually inscribing in Gadjo Dilo. Is he directly discussing the situation of Romanian Gypsies and their ostracization from Romanian society? Or is he not implicitly referring to a closer situation, 'at home' and the French climate and laws that have been enacted since the 1990s' surrounding immigrants, immigration, the flow of Roms (from Romania) entering France and the conditions they live in, the displacement of refugee populations, the homeless, and the third space of alterity created by Rom exclusion? Through his films Gatlif has become the voice of the disenfranchised, exiles, immigrants and homeless people. According to Positif critic Stéphane Goudet, Gatlif addresses a French man among Gypsies as much as Gypsies among Romanians, French people, Belgians, and other westerners (Goudet 1999, 69).

Gatlif started to make films in 1973 (see filmography). After the movie La Terre au ventre (1978), he decided to devote himself entirely to his people, and his subsequent three movies, Les Princes (1983), Latcho Drom (1991-92) and Gadjo Dilo,do just that, albeit in different genres. These form part of his 'Gypsy trilogy.' Similarly, his 1996 adaptation of Jean-Marie Le Clézio’s short story Mondo, about the uncanny appearance of a young nomad and Gypsy boy in a Mediterranean city, complement the series:

Depuis Latcho Drom, je ne fais plus des films pour régler mes comptes avec des gens qui n'aimeront jamais ni les Tziganes ni les Arabes parce qu'ils auront toujours besoin de boucs 
émissaires. Je me bats pour l'image de ce peuple tzigane qui, depuis qu'il est arrivé en Europe, a été chargé de tous les vices, de tous les péchés (quoted in Virgo 1998, 2). ${ }^{5}$

Gatlif, as a keeper of memory and images, also introduces a world of music to films whose scores he is known to write. One of his latest films, Vengo (1999) tells a story of vengeance-Gypsy style, in a Spanish countryside setting. Shot in black and white, sequences about dancing and Gypsy music punctuate the film. However, this might be a flaw in the process, which has been critically viewed by Gypsy spectators and critics. Gatlif stands out as an outsider to Roma culture in Romania, and therefore, despite the actual location, and the use of Roma actors, neither Romain Duris nor Rona Hartner, who plays the female lead role, are Gypsies. Scholars of Gypsy culture also inform us that Gypsies are reluctant and cautious about letting any information out to non-Gypsies; this would of course make it impossible for a filmmaker to film Gypsy culture:

Unlike Christians, for example, the way in which Gypsies choose not to reveal themselves to outsiders is in fact what is noteworthy. It is commonly reported that a Gypsy, when granting an interview to a non-Gypsy, uses the occasion to disseminate wrong information about Gypsy culture. Gypsy names and rituals lose their magical effectiveness if uttered to non-Gypsies (Carmichael 2001, 124).

A few associations are made between the French and Romanian Gypsies, linking both groups, yet they occur at one brief moment when Izidor, the old Gypsy, proudly introduces Stéphane to a small group of villagers in a small village tavern and informs them about Gypsies in France: 'In France', he says, 'there are Gypsy [Roma] doctors, engineers, advocates, they live in big houses, drive big cars, they speak Romany, hell, everyone speaks Romany. In France they love the Gypsies’. A fat, beefy, red-eyed nonGypsy European villager then asks Izidor, 'If they love you so much in France, why don't you and your people leave our country?' (Devi, n.d. Retranscription of the dialogue taking place borrowed from her review.) The sarcasm directed at Izidor concerning France, the country where immigrants used to flock to in order to live 'like God in France' is a sarcastic indictment of the current situation in France where immigrants are turned down and sent back.

\footnotetext{
5 'Since Latcho Drom, I no longer make films to settle scores with people who will never liked Gypsies or Arabs as they will always need scapegoats. I fight for the image of the Gypsy people who, since they arrived in Europe, were always made responsible for all the vices and sins.'
} 
The film may perpetrate the stereotypes associated with Gypsies in their link with exoticism and act more as an ethnographic adventure into Gypsy land, its music and women, initiating Western spectators to the seductive qualities of Gypsy music and exotic rituals, turning the frozen dirt roads of Romania into a sensual road experience. Gypsies and their culture, even if misunderstood, have throughout history paradoxically remained the object of curiosity and desire in literature, opera librettos, theatre plays, and more recently films:

We should not also forget that most people at this time already had some notions of Gypsies who had for centuries been a favorite literary theme and part of an iconographic tradition. The literate public knew them as beautiful young women and terrifying witches, as magicians and agents from a magic realm, as highwaymen and exotic misfits (Lucassen, Willems \& Cottar, 22).

In Gadjo Dilo the French traveler accesses a Gypsy culture usually off-limits to nonmembers and becomes near native. He will successfully perform or mimic the rituals that he has observed. In doing so he participates in the culture and seems to become one of them; yet, my reading of the film and of the culture questions the authenticity of such an experience. Has Stéphane truly become a cultural Other, a Gypsy, reproducing the rituals he has witnessed, running away on the roads with Sabina? Has not the search for Nora Luca been abandoned in order to pursue a more urgent one? Or more importantly, has Stéphane not opened to the world of Roms and gained access to another culture, miles away from his origins and preoccupations? These are all questions raised by the film but which Gatlif does not answer. At times, the filmmaker signals the dangers of a disappearing world, with the sudden outbreaks of violence in the village that had until then appeared unruffled and distant from Paris, the other exotic site. A graphic pogrom scene takes place at the end of the film, with villagers hunting down Izidor's son and burning him alive in his hide-out. Interestingly, Stéphane does not witness this scene and is off-camera when it occurs.

The timing of the film points to the possible entrance of Romania in the European Union along with other Eastern European countries, such as Poland, and Bulgaria. As such, in 2005, Romania and Bulgaria are both candidates for the European Union, whereas Poland became part of the European Union in 2004. It also, more than ever, demonstrates that Europe's borders have disappeared, and one can wander 'freely about the Continent as if 
it were your own country' (Fusel 1996, 52). Ultimately, it shows the effects of globalization in a small faraway community where American inscriptions have somehow found their way onto children's tee shirts.

The traveler, Stéphane, is no longer the impassible observer that is shown as traditionally white, male. However, despite his own position, he joins the ranks of other travelers in travel narratives, who shed their Eurocentric notions for a part in cultural Otherness. In many ways, the film participates in a renewed romanticism that accompanies the end of the twentieth century, with the figure of nomadism as the archetype of a postmodern (discontinued) temporality. The narrative is about a genealogical loss, a loss of a father, a loss of a son, a loss of roots, a loss of a culture, and about the discovery of, and thirst for, other cultures. In many ways, Gatlif projects himself onto the character of Stéphane and initiates the actor to Rom culture. Yet, as Roma scholar (and linguist) Ian Hancock signals, the current level of awareness about Gypsies shows a failure to understand the culture:

New-age travellers have confused the issue, leading some to think that being a Gypsy is a matter of lifestyle. The recent immigration of refugees from central and Eastern Europe and their demonisation by the tabloid press have only exacerbated the misunderstanding (Hancock 2002, 1).

Gatlif's film points to the emergence of a new area of studies, across national borders, of a group of people that have been marginalized and under-represented in fiction films thus far, with a few exceptions that usually stay with the exoticization of the Gypsy as 'Other.'

'I even met happy Gypsies’. (Final lyrics in Gadjo Dilo)

\section{Filmography}

1973 Max l'Indien (short)

1973 Maussane (short)

1975 La Tête en ruines (unreleased)

1978 La Terre au ventre

1982 Corre Gitano (unreleased)

1983 Canta Gitano (short)

1983 Les Princes

Portal Vol. 2, No. 2 July 2005 
1985 La Rue du départ

1989 Pleure pas my love

1990 Gaspard et Robinson

1993 Latcho Drom- Safe Journey

(Un certain regard award, Cannes 1993)

1995 Lucumi, l'Enfant Rumbeiro de Cuba (short)

1996 Mondo

1997 Gadjo Dilo-L'Etranger Fou. The Crazy Foreigner

(César award for best musical composition. Locarno Silver Leopard, 1997. Grand prix

spécial des Amériques, Montréal)

1999 Je suis né d'une cigogne

2000 Vengo- I come

2002 Swing

2004 Visions d'Europe: Paris by Night (segment)

2004 Exils- Exiles

(Best Director Award, Cannes 2004; nominated for music composition, Cesar 2005)

\section{Reference List}

'A Gypsy Awakening', The Economist, 11 September 1999.

Ang, I. 1992, 'Hegemony-in-trouble: Nostalgia and the Ideology of the Impossible in European Cinema', in Screening Europe: Image and Identity in Contemporary European Cinema, ed. D. Petrie, British Film Institute, London.

Barthes, R. 1981, Camera Lucida: Reflections on Photography, trans. R Howard, Farrar, Straus and Giroux, New York.

Carmichael, C. 2001, 'Gypsy Law and Jewish Law', in Gypsy Law: Romani Legal Traditions and Culture, ed. W.O. Weyrauch, University of California Press, Berkeley, 117-36.

Devi, G. n.d. 'Review of Gadjo Dilo' [Online]. Available: http://www.indiastar.com/gayatridevi.html.

Gadjo Dilo, (The Crazy Stranger) [motion picture] 1997, Paris, Prince Films

Gatlif, T. 2004, 'Interview with Bernard Pivot', Double Jeu, No. 29, December.

Goudet, S. 1999, 'Cinéma et Société', Positif, 457, (Mars), 68-70.

Hancock, I. 2002, We are the Romani People, University of Hertfordshire Press, Hatfield UK.

Kaplan, C. 1996, Questions of Travel: Postmodern Discourses of Displacement, Duke University Press, Durham NC. 
Laderman, D. 2002, Driving Visions: Exploring the Road Movie, University of Texas Press, Austin TX.

Lepidis, Clemen 1973, L’Arménien, Seuil, Paris.

Lucassen, L., Willems, W. \& Cottaar, A. 1998, Gypsies and Other Itinerant Groups: A Socio-Historical Approach, Macmillan Press and St. Martins Press, London and New York.

Naficy, H. 2001, An Accented Cinema: Exilic and Diasporic Filmmaking, Princeton University Press, Princeton.

Thompson, N. 2000, 'Understanding the Gulf: Tony Gatlif's Gadjo Dilo', Central Europe Review [Online], no. 41, November. Available: http://www.cereview.org/00/41/kinoeye41 thompson.html.

Vigo, L. 1998, 'Gadjo Dilo Tony le fou...de cinéma. Entretien avec Tony Gatlif', Regards, no. 34, (Avril).

Weyrauch, W.O. \& Bell, M. A. 2001, 'Autonomous Lawmaking', in Gypsy Law: Romani Legal Traditions and Culture, ed. W.O. Weyrauch, University of California Press, Berkeley CA. 